\title{
Interests, ideas and legacies of the past: Analysing the positions and strategies of Swedish policy actors in the establishment of the European Research Council
}

Bo Persson

The self-archived postprint version of this journal article is available at Linköping University Institutional Repository (DiVA):

http:// urn.kb.se/ resolve?urn=urn:nbn:se:liu:diva-139696

N.B.: When citing this work, cite the original publication.

Persson, Bo, (2017), Interests, ideas and legacies of the past: Analysing the positions and strategies of Swedish policy actors in the establishment of the European Research Council, European Educational Research J ournal (online), 17(3), 404-420. https:// doi.org/ 10.1177/ 1474904117719142

Original publication available at:

https:// doi.org/ 10.1177/ 1474904117719142

Copyright: SAGE Publications (UK and US)

http://www.uk.sagepub.com/home.nav 


\title{
Interests, ideas and legacies of the past: Analysing the positions and strategies of Swedish policy actors in the establishment of the European Research Council
}

European Educational Research Journal 2018, Vol. I7(3) 404-420

(C) The Author(s) 2017 Reprints and permissions: sagepub.co.uk/journalsPermissions.nav DOI: 10.1 I77/|474904|I77|9|42 journals.sagepub.com/home/eer

@SAGE

\section{Bo Persson}

Linköping University, Sweden

\begin{abstract}
In the past decade, the number of EU policy activities in research and higher education has increased greatly. The governance processes in these areas are increasingly characterized as multilayered, involving actors with a variety of roles, functions and loyalties. This article focuses on the forces shaping the policy positions and strategies of national science policy actors and coalitions in transnational policy processes through a case study of the positions, ideas and strategies held by central Swedish science policy actors in the process of building the European Research Council (ERC) during the first decade of the 2000s. The case is analysed from the perspectives of three versions of neo-institutional theory, each of which has somewhat different views on how institutions, interests and policy ideas interact in these kind of processes. The analysis shows that the Swedish influence on this process consisted primarily of an advocacy coalition of individuals with strong institutional positions in the Swedish science policy system and affiliations to transnational policy institutions and communities. Furthermore, the study shows that the policy actors largely functioned as normative entrepreneurs who related to general policy ideas shared by members of a transnational community, but also that the drivers of the development and the policy solutions were largely anchored in experiences and legacies from a national context.
\end{abstract}

\section{Keywords}

Research policy, European research policy, policy entrepreneurship, knowledge policy, coalition building, institutional theory

\section{Corresponding author:}

Bo Persson, Division of Political Science, Department of Management and Engineering, Linköping University, SE-58I 83 Linköping, Sweden.

Email: bo.persson@liu.se 


\section{Introduction}

In the past decade, the number of EU policy activities in research and higher education has increased greatly. The aims of building both a European Research Area (ERA) and European Higher Education Area (EHEA), and the vision of a Europe of knowledge have driven the integration of national policies and led to new institutions and initiatives (Chou and Gornitzka, 2014; Maasen and Olsen, 2007; Wedlin and Nedeva, 2015). The governance processes in these areas are increasingly characterized as multilayered, involving actors with a variety of roles, functions and loyalties. New transnational institutions, such as academic associations with a European scope, are often important arenas for mobilization and discussion of policy issues (Braun, 2015; Grande and Peschke, 1999; Lawn and Lingard, 2002). This kind of policy-making process is often described as being dominated by transnational networks of government agencies, experts and politicians (Börzel and Heard-Lauréote, 2009; Haas, 1992; Slaughter, 2004).

This article will focus on the forces shaping the policy positions and strategies of national science policy actors and coalitions in transnational policy processes. Recent analyses of European higher education and research policy have focused mainly on the process of European integration, and the related roles of national strategies and the European Commission (EC) (Chou and Gornitzka, 2014; Edler and James, 2015; Wedlin and Nedeva, 2015). Less is known about the positions and strategies of central national policy actors: for example, representatives of universities, research funding bodies, government bureaucracies and ministries, the coalitions and networks that these people form in the development of policy ideas and proposals in transnational processes, and how these should be understood. Do the positions and strategies of these actors reflect national state interests, the missions of specific organizations or interest groups, or the ideas of transnational communities and networks? Are the transnational arenas and networks used by these actors and coalitions to gain influence and to spread ideas in European policy-making? It is often claimed that national policy networks are increasingly nested within a European science policy subsystem, so they may share many ideas about the institutionalization of the 'contract of science' at the European level (Börzel and Heard-Lauréote, 2009). However, the policy ideas of leading actors in national science policy networks are anchored in different institutional contexts. Such ideas are expressed in the role and autonomy of universities, the function of research councils and the degree of political control over research and higher education that may be assumed to shape normative positions and definitions of interests in these areas (Benner, 2012; Lebeau and Papatsiba, 2016).

The aim of this article is to shed light on this issue through a case study of the positions, ideas and strategies held by central Swedish science policy actors in the process of building the European Research Council (ERC) during the first decade of the 2000s. The case is particularly interesting, because representatives of Swedish research funding bodies and academies were active in several phases of the construction of the idea of the ERC, and seem to have had a strong influence on the process (Gornitzka and Metz, 2014; Gronbaek, 2003; König, 2016; Luukkonen, 2014). My study describes the roles of the Swedish policy actors and analyses what shaped their positions and strategies. Were their positions and strategies based on national or organizational interests? Were they reflections of previous patterns of problem solving, or were the actors carriers of the ideas of transnational communities and networks? How did the different loyalties and institutional affiliations (national and European) of the actors interact in the development of these positions and strategies? I analyse these questions from three different neo-institutional perspectives. Although the perspectives provide alternative lenses through which to examine the subject, I also show the benefits of combining them. Clarifying how new policy ideas and solutions are shaped from a 'bottom-up' perspective, while focusing on the role of leading policy actors in the national arena, will increase our understanding of the conditions and development of knowledge policy in Europe (cf. Börzel, 2003). 
In the second section of this article, I present the theoretical starting points of my analysis in more detail. Section 3 describes the methodology and data of the empirical study. In the fourth section, I first provide a general overview of the establishment of the ERC and the roles of Swedish science policy actors in this process before analysing the results using the three theoretical lenses mentioned above, and discussing how they can be combined. In the fifth and final section, I present conclusions.

\section{National science policy actors in the transnational arena: A theoretical discussion}

In this article, I focus on the policy positions and strategies of national policy actors and coalitions in creating the ERC. My overall perspective is inspired by literature on policy networks, subsystems and coalitions. The starting point of my analysis is that, in line with this literature, the "policy actors' are all those involved in addressing a policy problem or issue. This set of policy actors can include people in a variety of positions: elected and agency officials, interest group leaders and researchers. In the science policy area, representatives of universities, research funding organizations and leading politicians are examples of actors of obvious interest for the study. Second, these subsystems of actors - to use the concept of Sabatier and Jenkins-Smith (1993) - can be observed at different levels of political systems. Hence, national science policy subsystems, which are at the core of our analysis, are nested within a European science policy subsystem. Third, I argue for grouping policy actors by 'advocacy coalitions' based on 'shared beliefs and coordinating strategies' (Jenkins-Smith et al., 2014; Sabatier and Jenkins-Smith, 1993).

How, then, can we understand the complex roles of national actors and coalitions in institution building at the European level and, in this case, in the establishment of a new research funding body at a transnational level? Below, I discuss three perspectives on the positions and strategies of national policy actors and coalitions in this kind of process. These perspectives, grounded in different versions of neo-institutional theory, put forward somewhat different views on how institutions, interests and policy ideas interact in such a process. I share the view of Dowding (1995: 44) that 'institutions contain a structural suggestion as to actor behavior'. However, different research approaches have interpreted the relations between institutions, ideas and interested actors in different ways, and they vary in terms of their compatibility with other perspectives. Of specific relevance for my study are the roles of the so-called 'policy ideas' behind this institutional solution (the research council model). In this study, policy ideas are defined as beliefs about cause-and-effect relationships in relation to solving particular policy problems (Campbell, 2002; Goldstein and Keohane, 1993). However, I also discuss how these policy ideas are anchored in more general, macro-scale ideas (such as paradigms or worldviews).

First, the rational choice institutional perspective focuses on the policy process as a power game. The political and distributive aspects of the process are emphasized, and the national policy actors and coalitions focus primarily on furthering their own interests in relation to other actors. From this perspective, national policy actors are largely characterized as maximizers of gains in the form of larger budgets or advantages for the actors they represent (such as scientists). Winning the battle over how new institutions (such as the ERC) should be designed is also a way to determine how resources and values will be distributed in the future. In this view, how these interests play out will depend greatly on the institutional structure of the organizations and the rules of the game, which prescribe, proscribe and permit behaviour (Moe, 1990).

Of course, a central issue for this perspective is identifying whose interests actors (and often organizations) represent. This is not at all clear. In some respects, a research funding agency might represent an organizational interest, a section of the scientific community or the government. At 
times, an academy might be characterized as a peak organization (representing the scientific community) or, on other occasions, the government. Hence, these actors can be characterized both as representatives of the scientific community and as public servants (bureaucrats, experts), but within different institutional contexts in terms of independence from the state. Here, the multilevel activities of the actors are naturally very relevant. National policy actors can be assumed to be involved in negotiations and power games, sometimes in alliances with politicians (such as ministers), and sometimes partly in opposition to them, for example, through the many committees that prepare and shape the decisions of European institutions (Börzel and Heard-Lauréote, 2009; Christiansen and Larsen, 2007).

A central strategy related to the rational choice institutional perspective is that of policy actors building coalitions with other actors to strengthen their positions. For example, leading policy actors may attempt to use transnational negotiations to further their interests in the national arena (Keohane and Nye, 2012). Hence, leading bureaucrats can function as coalition-building entrepreneurs at both the national and transnational levels (Schlager, 1995). However, as Mats Benner points out, research funding agencies and universities are often considered to be loosely coupled organizations with connections in different directions and a weak capacity for coordination (Benner, 2012). This state of affairs, which according to this perspective can be interpreted as the institutional structure (the rules of the game) for collective action in the policy process, demands strong individual policy entrepreneurs to mobilize interests (Ostrom, 1990). For this perspective, policy ideas such as the research council model are primarily viewed as road maps to behaviour in uncertain circumstances rather than independent factors. In other words, policy ideas function as 'focal points' in situations without unique equilibria (Goldstein and Keohane, 1993).

Second, the historical institutional perspective emphasizes that the positions and strategies of actors and coalitions are anchored in legacies of the past. Researchers in the field of historical institutionalism emphasize the importance of critical junctures and path dependency. They point out that institutions and policy decisions are the result of complex historical processes, as suggested by concepts such as 'policy legacy', 'path dependency', 'feedback processes' and 'critical junctures' (Thelen, 1999). These concepts all express the idea that changes in policies and institutional arrangements often represent reactions to, or consequences of, institutional policies or previous directions. While rational choice institutionalists tend to focus on the functional role of an institution (such as that of research councils in research policy), historical institutionalists are more interested in the origins of an institution and the often unintended consequences.

This line of neo-institutional theory emphasizes the fact that policy changes often begin in the organizational structure and capacity of the state; existing organizations, programmes and policies are the starting points of reform. Bo Rothstein, for example, has emphasized that, over time, the institutional structure of labour market policy in Sweden has shaped the interests of the labour unions; the actors have gradually adapted not only their strategies but also the definitions of their interests, ideas and other factors (Rothstein, 1996). This perspective also emphasizes the sequential logic and the feedback mechanisms of policy processes. The battles over new ideas and the construction of new institutions depend on earlier sequences, and are often reactions to previous processes (Thelen, 2004). The role of policy ideas in this perspective is not clear-cut, but Peter Hall uses the paradigm concept to describe overarching ideas that specify how the problems facing policy-makers are to be perceived, what goals might be attained through policy and what techniques can be used to achieve them (Hall, 1993). While policy ideas in rational choice institutionalism are supplementary to institutions, paradigms are strongly anchored in institutions and shape the precise policy ideas and solutions that are considered.

The third perspective that I take focuses on science policy actors as carriers of ideas and normative entrepreneurs. This approach to the problem is inspired by institutional perspectives that focus 
on the central roles of ideas and norms, such as normative and discursive variants of institutionalism (Peters, 2010). In this literature, the ideas are not just auxiliary explanations of interests and strategies, but justify and legitimize them. As normative institutionalism emphasizes, this perspective does not only involve ideas as normative guidelines, but also cognitive policy ideas (Schmidt, 2008). Researchers analysing policy processes emphasize the importance of the development of ideas that are not necessarily anchored in organizations. Instead, from this perspective, new policy ideas often develop among networks of actors. In the transnational arena, the term epistemic community describes how actors below the state level, such as government agencies, policy analysts and experts, are united as a community because of their 'shared belief or faith in the verity and the applicability of particular forms of knowledge or specific truth' (Haas, 1992: 3). Therefore, the development of ideas by national policy actors is highly dependent on these professional networks and common ideas. It is often assumed that the actors are seeking consensus and are open to professional ideas, rather than exercising power.

However, the focus in this case is not on the passive adaptation of actors and coalitions to institutional environments, but on the fact that they are often active entrepreneurs and carriers of policy ideas. Schmidt (2008: 310) describes these as 'the individuals and groups at the center of policy construction who are involved in the creation, elaboration, and justification of policy and program ideas'. For example, Finnemore and Sikkink (1998) have shown how actors can function as normative entrepreneurs in international politics. Normative entrepreneurs are actors with 'strong notions about appropriate or desirable behaviour' within a policy area (Finnemore and Sikkink, 1998: 896). They also state, 'Ideational commitment [rather than material interest] is the main motivation when entrepreneurs promote norms or ideas' (Finnemore and Sikkink,1998: 898), which separates them from the traditional rational choice institutional perspective. Furthermore, they indicate that these entrepreneurs are anchored in organizational platforms, but focus primarily on transnational organizations. Although Finnemore and Sikkink mainly used their concept to analyse international politics, in this study I use the concept of the normative entrepreneur to mean those with strong notions about certain policy ideas who seek support for them in policy processes.

My empirical analysis will take these perspectives as its starting point, and I show that they may inform interpretations of the positions and strategies of Swedish policy actors. However, I treat the perspectives as complementary and demonstrate how they can be combined. In fact, the perspectives described above are in many ways purifications. In practice, many neo-institutional studies combine experiences from somewhat different bases. For example, while historical institutionalism emphasizes the policy legacies of institutionalized practices, it also emphasizes that actors within the limits of these structural constraints seek power to achieve policy objectives. My foremost ambition in this study is to show how the idea-oriented perspective complements the other two. Many scholars inspired by neo-institutionalism have sought to integrate idea-oriented perspectives into rational and historical institutional approaches. Blyth (2002), for example, argues that the dualism between ideas and interests should be seen as constructed, and that analysts should see interests as being necessarily 'ideationally bound', particularly in situations of uncertainty, of which research policy may be a good example.

\section{Methodology and material}

The article follows a case study methodology. In the words of George and Bennet (2004: 18), the purpose is to analyse a 'well-defined aspect of a historical episode' that the investigator has selected for analysis. The aspect of interest here is the determination of what shaped the policy positions and strategies of central Swedish science policy actors in the process of building the ERC. The analytical approach can be characterized as a reflexive critical analysis, whereby I interpret the 
roles, positions, ideas and strategies of the actors, and analyse these based on the theoretical perspectives discussed above.

I have relied primarily on written sources. Policy documents, such as bills submitted by the government, annual reports, investigations, and evaluations by organizations and agencies, were important for describing the formal positions of the actors in the process, and interpreting their interests and ideas. Articles from newspapers and journals (featuring interviews with key actors, debate articles and the like), were important for understanding the positions of individual actors. The process of building the ERC has been analysed in a number of other texts (see, especially, König, 2016); these analyses were important sources of information on the overall process and the role of Swedish actors. I have also used data from my own research on Swedish research and innovation policies. In this case, the data were derived from interviews, documentary sources and historical studies (Persson 2001; Persson 2012).

Finally, to complement the written sources, I conducted interviews with four Swedish policymakers and advocates of the ERC in Sweden, who were identified as key people in the process. These were: Dan Brändström, former director of the Swedish Foundation for Humanities and Social Sciences (Riksbankens jubileumsfond (RJ)); Pär Omling, former director of the Swedish Research Council (Vetenskapsrådet (VR)); Michael Sohlman, former secretary of the Nobel Foundation; and Gunnar Öquist, former secretary of the Royal Swedish Academy of Sciences (Kungliga Vetenskapsakademin (KVA)). The interviews were semistructured, and focused mainly on the positions, strategies, motives and ideas behind positions, and the contexts of the events. It is important to emphasize that these interviews complemented and extended information from written sources. Because there are obvious reliability problems with interviews (such as bias and poor recall), it was important to crosscheck data by comparing it with that from other sources.

\section{Analysis of the results}

In this section, I describe and analyse the empirical results. I begin with a general overview of the establishment of the ERC and the roles of Swedish science policy actors in the process. I then analyse the results using the three theoretical lenses mentioned above. Finally, I discuss how the perspectives can be combined.

\section{The rise of the ERC and the role of Swedish actors in the process: An overview}

For some time, research policy in the European community and the issue of a research funding organization were primarily a matter of intergovernmental relations (for example, support for 'big science'). Although the establishment of a research council was discussed as early as the 1970s, the resulting European Science Foundation (ESF) did not function as a funding agency, but primarily as a coordinating body for national research councils. During the 1980s and 1990s, both the power and ambitions of the European research policy increased. The main evidence for this can be found in the multiannual research initiatives, called framework programmes, which have been launched regularly since the mid-1980s. Originally, these programmes focused primarily on research targeted at industry, and the stimulation of transnational cooperation. Hence, they were strongly inspired by bureaucratic and mission-oriented research funding organizations, characterized by negotiations between stakeholders and closely connected to political priorities; they were not organized like research councils (Guzetti, 1995; cf. Gornitzka and Metz, 2014).

In the early 2000s, the issue of a ERC once again appeared on the agenda. A number of leading scientists, lobbyists and science policy-makers started to promote a stronger focus on basic science and the establishment of a research council to complement the framework programmes. In general, 
the focus of the proposals was that the European countries lagged behind the US in scientific excellence, and advocates often mentioned the US National Science Foundation (NSF) as the role model for a new organization. The development coincided with the EC's increased focus on research policy through the Lisbon strategy and the launch of the ERA. There was also a strong critique of the framework programmes. In the public debate the instrument was sometimes considered bureaucratic, associated with too much political interference and only in the short-term interests of the industry concerned (Gronbaek, 2003). It was also based on the principle that at least in practice, each country would 'get its money back', rather than on open competition, which meant that it did not lead to research of high quality (Banchoff, 2002; König, 2016). While EU research was traditionally precompetitive and focused on cooperation and transnational collaboration, the ERC - in line with the research council model - would focus on basic research, open competition and scientific excellence (König, 2016).

Eventually, the ideas for a research council were translated into action. The proposal for a research council was formally put forward by an expert committee in 2004. After a process of lobbying and negotiation, and despite initially strong resistance, it was established in 2007 . The resistance was based on objections from national governments, such as lack of trust in the EU project and concerns about the national benefits, and from the EC, which initially argued that a council of this kind would be against the constitution of the EU (König, 2016). However, many observers seem to agree that in a relatively short time, despite this resistance, the ERC has become an established institution in EU research policy (Gornitzka and Metz, 2014; Nedeva, 2013). As several studies indicate, the Nordic, and especially the Swedish actors made important contributions with regard to advocating for and launching the ERC. Gronbaek, for example, asserts, 'Swedish scientists and science policy-makers have been in the vanguard of promoting the ERC' (Gronbaek, 2003: 396). Gornitzka and Metz state that 'a community of elite European scientists and science policy-makers with ideas of a radical change of European research policy found the Nordic states as coalition partners at the political level who formally launched the ERC on the political agenda' (Gornitzka and Metz, 2014: 89). The process of establishing the ERC can be divided into a number of stages. Swedish policy actors were important, especially in the early stages.

In the early $2000 \mathrm{~s}$, leading representatives of central research funding agencies such as the RJ, the VR and quasi-public organizations such as the KVA and the Nobel Foundation had already established an informal network to discuss the issue of a reformed EU policy. The network included government representatives and, temporarily, actors from other countries. Eventually, the committee was called the Swedish Committee for the Reform of European Research Policy (CNERP), and it became formally connected to the RJ. The committee described itself as a 'counter-movement', with the ambition of changing the direction of EU research policy. The main idea was to work for the ERC, which would have a role similar to that of the NSF in the US (Hansson, 2002). The network organized conferences, mobilized political actors (initially in Sweden) and negotiated compromises, but also used its members and the resources and contacts of member organizations to promote the new proposal. This network put the idea of a research council on the agenda of meetings and conferences during the Swedish chairmanship of the EU in 2001. In collaboration with Danish policy actors, the committee obtained support for the idea during the Danish chairmanship in 2002. The Danes took the initiative to create an expert group to prepare for the establishment of the ERC (Gronbaek, 2003).

Because the EC and several member countries were quite sceptical about the research council's proposal from the beginning, it became important for the members of this expert group to use their contacts with transnational organizations for influence and lobbying activities. In this expert group, Dan Brändström of the RJ, in particular, had a leading role in the process (König, 2016: Gunnar Öquist, 2016, personal communication; Riksbankens jubileumsfond, 2003). Central Swedish actors 
in the national network also had important positions in transnational organizations and networks (the ESF) and the coordinating organization for the European research funding organizations (EUROHORCS) (Gronbaek, 2003; Pär Omling, 2016, personal communication; Gunnar Öquist, 2016, personal communication). Michael Sohlman, executive director of the Nobel Foundation, was able to mobilize a network of Nobel Prize winners in support of the idea. He had good contacts with important research policy actors in other parts of Europe, not least in France, and these were contacts that he was able to utilize at crucial phases of the process (Dan Brändström, 2016, personal communication; Gronbaek, 2003; Michael Sohlman, 2016, personal communication).

Naturally, this process must be seen as only a part of larger multinational negotiations. While the strong influence of a relatively small country such as Sweden is interesting and, perhaps, unexpected, the focus of this article is not to evaluate its relative influence on the outcome. While the above description shows that a coalition of Swedish policy-makers was active in several phases and levels of the process, the focus is now on interpreting the positions and strategies of these Swedish policy actors in this process.

\section{A rational choice institutional perspective: Institutions and interests at stake}

According to the rational choice institutional perspective, the institutional structure of science policy-making is crucial to the positions and strategies of the key actors. As Mats Benner has pointed out, science policy in Sweden is often described as a relatively loosely coupled system, with weak central coordination (Benner, 2012). Generally, research policy in Sweden has been decentralized to universities and to research funding agencies, including research councils mainly controlled and steered by representatives of the scientific community and mission-oriented agencies more clearly driven by public policy objectives, and usually governed by representatives of various stakeholders. Although this is also the case in many other industrial countries, this characteristic is especially strong in the Swedish dualistic system with small weak ministries, where much of the implementation is performed by autonomous government agencies (Benner, 2008; Persson 2001). Furthermore, an important characteristic is that universities, which carry out most public research in Sweden, have been highly dependent on external competitive funding (in contrast to institutional funding) from research agencies and councils (Vetenskapsrådet, 2008: 15).

The other question that this perspective raises is what material interests were at stake for the Swedish science policy actors in the case of the ERC. As in other countries, there was a strong dissatisfaction that research funding in the framework programmes was bureaucratic and inefficient (Fölster, 1996; cf. Sveriges Riksdag, 2001). All the interviews confirm that this was a major issue for the actors in the process. In a scientific community strongly dependent on external funding, it would indeed be expected that low cost, predictable and competitive application procedures would be preferred to the more bureaucratic, unpredictable and costly funding that the framework programmes could be expected to offer. A related point in the process of establishing the ERC was the issue of who would gain from this new structure. In the new institution, national concerns were supposed to be relatively absent; the governing principle would be to support individual research teams from individual countries, not multinational teams. It was quite possible to expect that nations with a strong research history, such as the UK, Sweden and the other Nordic countries would gain from this arrangement, while other nations, for example, those in Eastern Europe, with less developed research infrastructures, would stand to lose (Gornitzka and Metz, 2014).

Given these structural problems, it was expected that the major ERC advocates in Sweden would be research funding agencies and representatives of the scientific community. In 2000, the VR - the result of the merger of the four existing research councils for basic research into a larger organization (at least formally) - had become the most important actor in Swedish research policy. It was the main 
funding organization of disciplinary research and basic sciences in Sweden, and it was responsible for coordinating state research funding. This role was emphasized throughout the Swedish system, in which the scientific community elected representatives to the council. Of course, this gave the VR significant legitimacy in the scientific community. As Pär Omling, the director of the VR during this period, stated, this was an issue where the council had a clear common interest: to strengthen basic research and research based on a peer review system (that is, the same as the research council). Apart from being closely related to the mission - the concept of a research council - the VR also had strategic motives for joining the discussion on the ERC. It was under strong pressure to function not only as a traditional research council relying on bottom-up research initiatives, but also as a strategic actor that would set priorities and take the initiative (Pär Omling, 2016, personal communication; cf. Vetenskapsrådet, 2010). In the 2002 annual report, the VR noted that the main reason to work for the ERC was to increase the efficiency and quality of research (Vetenskapsrådet, 2003). The RJ was also a strong funding actor, although not so much a 'representative actor' for the whole scientific community as the VR, since the RJ funds only social science and humanities research.

The KVA, which is an 'independent organization whose overall objective is to promote the sciences and strengthen their influence in society' (Kungliga Vetenskapsakademin, 2016), was an important organization in mobilizing leading scientists in the process. Two leading actors in the academy, Uno Lindberg and Gunnar Öquist, were members of CNERP (Riksbankens jubileumsfond, 2003). Furthermore, the KVA was an important representative of the Swedish scientific community, as well as having strong connections to other academies in Europe (Gunnar Öquist, 2016, personal communication). From this perspective, this network of actors can be described as a coalition with a strong common interest in guarding and advocating the positions of the Swedish scientific community, and the positions of their separate organizations.

What role did Swedish politicians play in this process, and what were their motives? First, the social democratic government had a generally positive view of research funding through research councils. It favoured support for basic research and had strategic reasons to support the proposal. The appointment of Thomas Östros as the new Minister of Education and Research was partly to restore the scientific community's confidence in the government. His predecessor, Carl Tham, had focused on the relevance and societal use of research, and the establishment of new regional university colleges. These efforts met with criticism from leading university representatives, particularly those from older universities (Benner, 2001; Persson, 2012).

The 2001 Swedish presidency provided a window of opportunity for discussion of the proposal for a council. As discussed above, before and during its presidency, Sweden oversaw a series of meetings related to European research policy, and the Swedish advocates successfully used those occasions to make their case. However, according to some sources, the Swedish Minister of Education was initially sceptical about the idea, and the Swedish government did not officially support the ERC during its presidential term. The science policy adviser of the government, Hans Wigzell, was a strong advocate of the ERC and, according to the same sources, together with the director of the VR, Pär Omling, he eventually convinced the Swedish minister to support the efforts of the committee (Edqvist, 2009; Pär Omling, 2016, personal communication; cf. Wigzell, 2002). On the other hand, at the beginning of the 2000s, the Swedish Minister of Education and Research expressed a strong wish for a stronger focus on basic research and making the research funding organization more like the research council model of the EU (Sveriges Riksdag, 2002). It is not a far-fetched view that the Swedish government saw this process as an opportunity for Sweden to play a role in European politics.

While the first steps of the process were mainly in the national arena, with informal contacts with actors in other countries, from 2002 the activities of the Swedish network of actors were more connected and dependent on the institutional framework of the EU institutions. In addition, these 
processes were governed primarily by informal negotiations and by representatives of funding agencies and interested organizations, for example, Nordic networks that were initially crucial in this process. The connections between the Nordic policy-makers were important in the EU policymaking process, as they often take similar positions on central issues (Sannerstedt, 2005). In this case, the Swedish and Danish positions on funding agencies (the Danish Research Council) were similar. Leading Danish science policy-makers, in conjunction with their Swedish allies, placed the issue on the Danish policy agenda (Gronbaek, 2003). In this case, agency representatives in collaboration with other stakeholders mobilized support at the national, regional (Nordic) and European levels. Transnational networks, not least those between Swedish and Danish funding organizations, were essential in building support for the idea of a research council (Dan Brändström, 2016, personal communication; König, 2016).

Interestingly, this was not a case of a coherent Swedish state strategy by a unified body; rather it was a bottom-up process where representatives of agencies and organizations in the scientific community were active participants (structured as a network); the leading politicians mostly reacted and confirmed in retrospect. Obviously, Swedish advocates of the ERC, in collaboration with other actors, saw advantages for the Swedish scientists, and indirectly for their organizations. As discussed above, the role of ideas - in this case, the research council model - is less important from this theoretical perspective. The idea of a research council should be interpreted as facilitating collective action among the actors. The focus on basic scientific research and increasing external funding for Swedish researchers should be seen as primary factors, while the specific solution, the research council, should be seen as secondary. To explain how the material interests of the central actors and institutional structures interacted with ideas, we now turn to the second institutional perspective, concerning path-dependent explanations for specific policy ideas.

\section{The historical institutional perspective: Legacies and previous events}

The historical institutional perspective emphasizes the fact that the positions and strategies of actors and coalitions are anchored in legacies of the past. In this case, it can be noted that the central characteristics of the research council model have demonstrated remarkable continuity over time. The legacy of the current structure of Swedish research funding agencies stretches back to at least the 1940s, when a number of research councils were established; some focused on basic research and some on mission-oriented research. As Torsten Nybom has shown, the solution for these research councils was not self-evident. Different models were discussed; for example, establishing new research institutes instead of directing funding through the intermediary structures of funding bodies. An important overall motive for the establishment of the new structure was that the state was eager to increase the coordination of resources devoted to science. This ruled out simply increasing research funding for universities and technical colleges. The universities preferred an increase in direct funding, so the council model (government agencies strongly anchored in the scientific communities) seemed like a clever compromise (Nybom, 1997).

Even though the mechanisms for funding research in Sweden have undergone various changes, the research council model has shown strong stability and adaptability. For example, from the 1960s onwards, the organization of research policy coordination and funding in Sweden was characterized by sectorization. Research was increasingly seen first and foremost as an instrument for achieving political goals, not as a political area in itself. Most ministries had a variety of sectorial agencies that handled research funding and established priorities in close relationships with sectorial interests. These agencies were not organized as traditional research councils, but more like traditional bureaucracies, influenced strongly by interest groups. However, during the late 1970s and early 1980s, the issue of external funding for Swedish universities received severe criticism. 
The central question was how the universities should manage the needs and commissions of sectorial research funding agencies. The universities suggested that this should be managed by transferring funding from research funders to themselves, which university authorities claimed would improve the long-term capacity for managing external projects. However, the policy of the government, which was driven by social democratic politicians with strong connections in the scientific community, was instead to force sectorial agencies to use the peer review process to manage applications from universities. This strengthened the influence of the research community, rather than that of the base funding of the universities. Hence, the research council model and the associated traditional and disciplinary structures were strengthened during this period (Persson, 2001). In the 1970s, the government introduced the principle that representatives of the scientific community in all research councils should be elected through a standardized voting system (electoral colleges elect the members), which strengthened the connections of the councils' systems to the scientific community and the universities (SOU, 1975).

In the late 1990s, the issue of strengthening the research councils was once again on the agenda, but this time the debate was strongly polarized. On the one side were actors who favoured making universities and researchers cooperate more with society and address the needs of industry; on the other were actors who wanted to strengthen the autonomy of universities and channel state research funding through the research councils (which was the same solution as in the 1980s). The result was quite a radical reform of the Swedish research funding system, at least on the surface. As mentioned earlier, a major change was the establishment of the VR, merging the four existing research councils for basic research into a larger organization with more 'muscle'. Furthermore, two new mission-oriented research funding councils were established, consisting of parts of earlier missionoriented research agencies and units. Unlike their predecessors, the new mission-oriented agencies were organized along much the same lines as the research councils for basic research; for example, they used the peer review process to make decisions about research grants, thus reflecting a strong influence by the research community. Finally, a new agency was created for needs-oriented research related mainly to growth and industrial policy - VINNOVA (Benner, 2001). A central point here is that, in one way, the idea of the research council model emerged strongly from this process. Apart from being the main state instrument for supporting basic research, it was also widely accepted as the main model for supporting so-called sectorial research. On the other hand, some of the research more relevant to society, especially industry-relevant research, came to be integrated into a new and broader innovation policy track, which institutionalized the conflict between the two coalitions (and their ideas for supporting research) in research policy-making.

What evidence is there that the positions and strategies of Swedish science policy actors are continuations on this path? First, as I have attempted to demonstrate above, we can observe a structural pattern in the use of the research council model as one based on peer review, governed by a scientific council and strongly anchored in the scientific community. However, the important point is that this is not a structurally determined outcome. Rather, it was strongly supported and nurtured by a coalition of actors, which made it an appropriate solution. Social Democrats in particular saw the research council model as an equitable way of steering science policy, and maintained this view in discussions on the ERC. One example is Sverker Gustavsson, who had been under-secretary of state in the Ministry for Education and Research in the 1980s, and one of the leading forces in making mission-oriented agencies more like research councils (see above) (Gustavsson, 2002; cf. Persson, 2001). Moreover, the positions and engagement of Swedish advocates of the ERC were based on their experiences of the research council model in Sweden and its design. One advocate stated that leading science policy actors had a generally positive view of the research council because it had proved to be an efficient model for national competitiveness in Sweden (Gunnar Öqvist, 2016, personal communication). Second, the process was clearly related to a conflict 
between coalitions and ideas in national research policy in the 1990s (see above). The national scientific community was dissatisfied with the 'hollowing out' of support for basic science during the 1990s, due to the cuts in basic research in favour of more applied research during the economic crisis, and creating the ERC would strengthen and support the coalition of advocates for both basic science and the research council model at the national level (Benner, 2001). Therefore, it appears that the previous sequence of events (a game that had just finished), which concerned a conflict between the research council idea and a more innovation-oriented policy, spilled over into the positions and strategies of the national actors at the transnational level (see the discussion in Sandström, 2002; cf. König, 2016: 36). The former director of the RJ, for example, states that his engagement in the process was shaped by his experiences in the late 1990s as secretary to the organizing committee for the new funding structure, where he and others had been advocates of the research council model (Dan Brändström, 2016, personal communication).

\section{An idea-oriented perspective: Policy actors as normative entrepreneurs}

The third perspective that I use focuses on science policy actors as carriers of ideas and normative entrepreneurs. This perspective emphasizes the central role of actors who share a common goal and central values in analysing the development of policies. Naturally, it is clear that the institutional solution discussed here, the research council model, is anchored in ideas about research funding that dominate research policy-making in many countries. These ideas have spread between countries since the early post-war period, and they are anchored in the processes of a large scientific community. This is similar to what Haas characterized as an epistemic community - one that consists of advocates for this institutional solution, at least as a general mechanism for funding. However, there does not seem to have been strong consensus over the proposed ERC (Gronbaek, 2003).

In many ways, the behaviour of the Swedish advocacy coalition working for the ERC has characteristics resembling those of a 'normative entrepreneur', in that it acted as a carrier and advocate of beliefs and solutions anchored in certain ideas and beliefs, and that the actors seem to have been driven by ideas and ideational commitment. Especially in the interviews, it is clear that the actors share a common discourse with the principles of the research council model. They adhere to values such as 'competitiveness', 'equity' and 'scientific quality', while the framework programmes are associated with values such as 'bureaucratic', 'political steering' and 'pork-barrel politics' (Edqvist, 2009; Hansson, 2002; Interviews). As in other policy areas, such as welfare policy and peacekeeping (cf. Björkdahl, 2008), there are signs that the Swedish actors perceive their roles as defenders and advocates of a specific policy idea. Indeed, it seems that the research council model appealed to public sentiments and norms in the Swedish policy system. For example, according to Thomas König's analysis of the ERC, the commitment of the Swedish science policy-maker group partly derived from a 'shared sense of mission of Sweden, where research policy had always had a special place and where the Nobel Foundation was only the most distinguished of several thousand other organizations dedicated to funding and rewarding scientific research' (König, 2016: 36). The interviews confirm that the actors all state that the idea arose from a belief system anchored in both the Swedish state and the scientific policy community. The interviewees even discussed their mission in terms of extending the 'Swedish model' of research steering, dominated by research councils and university research, to the European level.

As many sources confirm, as an individual and as a managing director of the RJ, Dan Brändström was central in mobilizing the Swedish network for the ERC. He was apparently driven by the 'idea of a research council' governed by peer review procedures, with the NSF as a role model. Brändström had been active in the research policy community since the early 1970s, and had considerable experience as a member of expert committees performing research evaluations and similar duties. In the late 1990s, as mentioned above, he was appointed secretary of the organizing committee that would 
implement the reform of the research funding organization (see above), which led to the establishment of the Swedish Research Council (Dan Brändström, 2016, personal communication). He also had strong connections to other science policy actors in Europe. Similarly, Gunnar Öquist, who had been the secretary of a research council in natural sciences in the 1990s, and Pär Omling, the director of the VR, describe themselves as strong advocates of the research council, and driven by ideological commitments ('visions' and 'altruistic motives') (CORDIS, 2001; Pär Omling, 2016, personal communication; Gunnar Öquist, 2016, personal communication).

When normative entrepreneurs are discussed in the literature, it is primarily as individual actors connected to epistemic communities and transnational institutions, where less focus is on their national institutional affiliations. For a long time, the RJ had supported research in social sciences and the humanities, but had also been an arena for discussions and activities concerning research policy-making and the role of universities (Samuelsson, 2014). Therefore, according to Brändström, the RJ could be a forum for advocating these. However, Brändström asserts that, although he could use the RJ as a platform for this work, the organization itself (for example, the board) was not very active in the process (Dan Brändström, 2016, personal communication).

Therefore, although the process analyzed in this article can, in part, be interpreted as actors mobilizing other actors in a power game, the case also shows how the actors functioned as advocates of norms and policy ideas. The ideas relating to the research council model and the autonomy of academic research, such as peer review processes, investigator-initiated research projects and equal competition, were important. They had strong legitimacy and wide acceptance as guiding norms for national research policy, not least in the northern and north-western EU member countries. The leading actors in the funding agencies (the VR and the RJ) and associated organizations formulated the idea of a research council and its role in strengthening the science capacity of Europe. In this respect, these agencies translated an idea grounded in a national context and a transnational community to a new context and discourse, that is, they were international normative entrepreneurs or advocates and coalition-building actors influencing the policy process at the European level.

\section{Discussion}

So far, the analysis of the case has been based on three distinct neo-institutional perspectives. The perspectives provide differing interpretations of the case, although I argue that in line with a strong tradition among scholars from the neo-institutional school of thought, they can also be complementary. First, the analysis of the rational choice institutional perspective focused on the process of establishing the ERC as a power game, emphasizing its political and distributive aspects. The analysis showed that the national policy actors and coalitions had strong material interests causing them to further their own organizations' concerns in relation to other actors, although this interpretation does not seem to provide a full understanding of the behaviour of the individual actors. Furthermore, the result highlights that this cannot be understood as a coherent state strategy by a unified actor; rather, it is a bottom-up process in which representatives of agencies and organizations in the scientific community are active (and function as an advocacy coalition), while the leading politicians mostly react and confirm decisions in retrospect.

The second perspective led me to analyse the case based on the historical institutional assumption that the positions and strategies of the actors and coalitions are anchored in common experiences and institutional legacies of national policy. I show how the research council model in Sweden can be interpreted as an institutionalized idea, advocated by a relatively stable coalition of actors over a very long period. This idea is not undisputed in the Swedish science policy system, but has been a dominant policy solution around which funding solutions have been discussed. As I have shown, we can observe a structural pattern in the use of the research council model as an idea based on peer review, governed 
by a scientific council and anchored in the scientific community. Furthermore, the process of establishing the ERC was clearly related to a conflict between coalitions and ideas in national research policy in the 1990s. In a sense, policy conflicts and the positions of the national policy subsystem were reproduced on the European agenda. Hence, this was not a deterministic development where the actors performed the role of structural support; rather, as scholars such as Kathleen Thelen argue, the development depended on the strategies of actors, although they adopted them based on feedback effects from previous events and in relation to existing solutions (cf. Thelen, 2004).

The third analysis focused on science policy actors as carriers of ideas and normative entrepreneurs and, in many ways, this analysis complemented the other perspectives. In the analysis, I demonstrate the importance of individual policy actors, who function as policy entrepreneurs in both national and transnational arenas and who are not primarily driven by power and material interests, but by policy ideas. To some extent, the actors can be viewed as part of a transnational community where ideas develop (a science policy community) but, in this case, these actors did not always achieve the strong consensus necessary to influence professional organizations and agencies. Interestingly, it seems instead that the policy ideas behind the positions and strategies of the actors are largely grounded in the general bureaucratic values of integrity and openness, as well as in a strong belief in the idea of The European Union project. Of course, this, in turn, may be related to strong beliefs in a strong but neutral state, and in the value of international cooperation, often associated with the policies and belief systems of the Nordic countries (cf. Björkdahl, 2008). Thus, while it is seems reasonable to conclude that material interests were important triggers of the process to establish the ERC, in addition to experiences and feedback from previous events in national policy, idea-driven policy actors, partly anchored in transnational communities, were important as normative entrepreneurs.

\section{Conclusion}

This article has highlighted the positions and strategies of national science policy actors and coalitions in transnational policy processes. While previous studies of this sort have often focused on state strategies (treating the state as a unified actor), the ambition of this article has been to examine more closely how domestic policy processes interact with transnational problems and issues, and what factors shape these processes. That is, the focus has been on a relatively complex governance process, where actors with different loyalties and institutional affiliations (national and European) interact. The more precise aim has been to shed light on this subject through a case study of the roles, positions, ideas and strategies of central Swedish science policy actors in the process of building the ERC during the first decade of the 2000s. The article has focused on describing the roles of the Swedish policy actors and analysing what factors shaped their positions and strategies. Were their positions and strategies based on national or organizational interests? Were they reflections of previous patterns of problem solving, or were the actors conveying ideas of transnational communities and networks? How did the various loyalties and institutional affiliations (national and European) of the actors interact in the development of these positions and strategies? The article clarifies how new policy issues and arenas are shaped from a bottom-up perspective, focusing on the role of leading policy actors in the national arena in order to explain the conditions and development of knowledge policy in Europe. Hence, unlike most studies of multilevel governance processes in Europe, this study is not about how international policies or ideas are interpreted in national contexts, but about the role of national policy networks in transnational policy processes.

The Swedish influence on the process of establishing the ERC consisted primarily of an advocacy coalition of individuals, with strong institutional positions in the Swedish science policy system and affiliations to transnational policy institutions and communities. Through national and transnational contacts, the coalition and its members played important roles as advocates and entrepreneurs. Furthermore, it is clear that this was not a top-down governance process steered by 
the Swedish government; rather, the government largely supported and gave legitimacy to positions and strategies in retrospect. In fact, in many ways, this reflects what is often described as the decentralized and loosely coupled structure of Swedish research policy, illustrating the importance of the rules of the game of the policy process. It is difficult to attribute the activities merely to the material interests of Swedish scientists; the policy actors as normative entrepreneurs are primarily driven by ideational commitment. Furthermore, the study highlights how the positions and strategies of the actors can be seen as continuations of national paths, both when they concern institutional solutions and the manner in which particular issues are framed. To some extent, the patterns of conflicts and the nature of previous events in the national arena were reproduced on the European agenda. Therefore, while the policy actors largely functioned as normative entrepreneurs who relate to general policy ideas shared by members of a transnational community, the drivers of the development and policy solutions were largely anchored in a national context.

Finally, based on this case study, I conclude that to understand processes and institutional change in European research policy, we need to highlight the importance of the ideas and policy legacies of national policy subsystems and coalitions. While formal top-down-oriented decisionmaking processes, such as the committee system and the EC's role as agenda setter, have received a fair amount of attention in studies of European science and technology policy, as has the role of transnational organizations and communities, studies of informal and bottom-up policy processes are less common.

\section{Acknowledgements}

The author is grateful to two anonymous referees for valuable comments on this article.

\section{Declaration of Conflicting Interest}

The author(s) declared no potential conflicts of interest with respect to the research, authorship, and/or publication of this article.

\section{Funding}

The author(s) disclosed receipt of the following financial support for the research, authorship and/or publication of this article: This research received no specific grant from any funding agency in the public, commercial or not-for-profit sectors.

\section{References}

Banchoff T (2002) Institutions, inertia and European Union research policy. Journal of Common Market Studies 40(1): 1-21.

Benner M (2001) Kontrovers och konsensus. Vetenskap och politik i svenskt 1990-tal. Stockholm/Nora: SISTER/Nya Doxa.

Benner M (2008) Kunskapsnation i kris? Politik, pengar och makt i svensk forskning. Nora: Nya Doxa.

Benner M (2012) Big science in a small country: Constraints and possibilities of research policy. In: Hallonsten O (ed.) In Pursuit of a Promise: Perspectives on the Political Process to Establish the European Spallation Source (ESS) in Lund, Sweden. Lund: Arkiv förlag, pp.159-172.

Björkdahl A (2008) Norm advocacy: A small state strategy to influence the EU. Journal of European Public Policy 15(1):135-154.

Blyth M (2002) Great Transformations: Economic Ideas and Institutional Change in the Twentieth Century. Cambridge: Cambridge University Press.

Börzel TA (2003) Shaping and Taking EU Policies: Member State Responses to Europeanization. Queen's Papers on Europeanisation No 2/2003. Belfast: Queen's University Belfast.

Börzel TA and Heard-Lauréote K (2009) Networks in EU multi-level governance: Concepts and contributions. Journal of Public Policy 29(2): 135-151. 
Braun D (2015) Actor constellations in the European funding area. In: Wedlin L and Nedeva M (eds) Towards European Science: Dynamics and Policy of an Evolving European Space. Cheltenham: Edward Elgar, pp.61-82.

Campbell (2002) Ideas, politics and public policy. Annual Review of Sociology 28(1): 21-38.

Chou M and Gornitzka $\AA$ (eds) (2014) Building the Knowledge Economy in Europe. Cheltenham: Edward Elgar.

Christiansen T and Larsen T (eds) (2007) The Role of Committees in the Policy-Process of the European Union: Legislation, Implementation and Deliberation. Cheltenham: Edward Elgar.

CORDIS (2001) Sweden's research shakedown provides clearer vision [Interview with Pär Omling]. Cordis. Available at: http://cordis.europa.eu/news/rcn/16859_en.html (accessed 20 May 2016).

Dowding K (1995) Interpreting formal coalition theory. In: Dowding K and King DS (eds) Preferences, Institutions, and Rational Choice. Oxford: Oxford University Press, pp.43-59.

Edler J and James AD (2015) Understanding the emergence of new science and technology policies: Policy entrepreneurship, agenda setting and the development of the European Framework Programme. Research Policy 44(6): 1252-1265.

Edqvist O (2009) Gränslös forskning: Om internationalisering av svensk forskning. Nora: Nya Doxa.

Finnemore M and Sikkink K (1998) International norm dynamics and political change. International Organization 50(2): 325-347.

Fölster S (1996) Hur effektivt är EU:s stöd till forskning och utveckling? En principdiskussion. Report to the Export Group on Public Economics (Ds 1996:8). Stockholm: Government Office.

George AL and Bennett A (2004) Case Studies and Theory Development in the Social Sciences. Cambridge, MA: MIT Press.

Goldstein J and Keohane R (1993) Ideas and foreign policy: An analytical framework. In: Goldstein J and Keohane R (eds) Ideas and Foreign Policy: Beliefs, Institutions and Political Change. Ithaca, NY: Cornell University Press, pp.173-206.

Gornitzka $\AA$ and Metz J (2014) Dynamics of institution building in the Europe of knowledge: The birth of the European Research Council. In: Chou M and Gornitzka Å (eds) Building the Knowledge Economy in Europe. Cheltenham: Edward Elgar, pp.111-130.

Grande E and Peschke A (1999) Transnational cooperation and policy networks in European science policymaking. Research Policy 28(1): 43-61.

Gronbaek D (2003) A European Research Council: An idea whose time has come? Science and Public Policy 30(6): 391-404.

Gustavsson S (2002) Resurserna finns också på denna sidan Atlanten. Dagens forskning, 7 January, 39.

Guzetti L (1995) A Brief History of European Union Research Policy. Luxembourg: Office for the Official Publications of the European Communities.

Haas P (1992) Introduction: Epistemic communities and international policy coordination. International Organization 46(1): 1-35.

Hall P (1993) Policy paradigms, social learning, and the state: The case of economic policymaking in Britain. Comparative Politics 25(3): 275-296.

Hansson T (2002) Kommitté vill ändra EU-politiken. Dagens forskning, 15-16 April, 9.

Jenkins-Smith et al. (2014) The advocacy coalition framework: Foundations, evolution, and ongoing research. In: Sabatier PA and Weible CM (eds) Theories of the Policy Process. Boulder, CO: Westview Press, pp.183-224.

Keohane RO and Nye JS (2012) Power and Interdependence. World Politics in Transition. 4th ed. Boston, MA: Longman.

König T (2016) The European Research Council. Cambridge: Polity Press.

Kungliga Vetenskapsakademin (2016) Home Page. Available at: www.kva.se (accessed 10 May 2016).

Lawn M and Lingard B (2002) Constructing a European policy space in educational governance: The role of transnational policy actors. European Educational Research Journal 1(2): 290-307.

Lebeau Y and Papatsiba V (2016) Conceptions and expectations of research collaboration in the European social sciences: Research policies, institutional contexts and the autonomy of the scientific field. European Educational Research Journal. Epub ahead of print 18 April 2016. DOI: 10.1177/1474904116642777.

Luukkonen T (2014) The European Research Council and the European research funding landscape. Science and Public Policy 41(1): 29-43. 
Maassen P and Olsen JP (eds) (2007) University Dynamics and European Integration. Dordrecht: Springer.

Moe T (1990) Political institutions: The neglected side of the story. Journal of Law, Economics, and Organization 6(Special Issue): 213-253.

Nedeva M (2013) Between the global and the national: Organising European science. Research Policy 42(1): $220-230$.

Nybom T (1997) Kunskap-politik-samhälle: Essäer om kunskapssyn, universitet och forskningspolitik. Hargshamn: Hjalmar \& Jörgen bokförlag.

Ostrom E (1990) Governing the Commons: The Evolution of Institutions for Collective Action. Cambridge: Cambridge University Press.

Persson B (2001) Motsträviga myndigheter. Sektorsforskning och politisk styrning under 1980-talet. Linköping/Stockholm: Tema Teknik och social förändring/SISTER.

Persson B (2012) Constructing an innovation policy agency: The case of the Swedish governmental agency for innovation systems. In: Rickne A, Laestadius S and Etzkowitz H (eds) Innovation Governance in an Open Economy: Shaping Regional Nodes in a Globalized World. London: Routledge, pp.162-182.

Peters BG (2010) Institutional Theory in Political Science: The New Institutionalism. 3rd ed. New York: Continuum.

Riksbankens jubileumsfond (2003) Annual Report. Stockholm: Riksbankens jubileumsfond.

Rothstein B (1996) The Social Democratic State. The Swedish Model and the Bureaucratic Problem of Social Reforms. Pittsburgh, PA: University of Pittsburgh Press.

Sabatier PA and Jenkins-Smith H (1993) Policy Change and Learning: An Advocacy Coalition Approach. Boulder, CO: Westview Press.

Samuelsson M (2014) Riksbankens jubileumsfond - 50 år av nyfikenhet. Stockholm: Riksbankens jubileumsfond.

Sandström U (2002) Polarisering: Reflektioner kring forskningsdebatten. In: Kim L and Mårtens P (eds) Den vildväxande högskolan. Nora/Stockholm: Nya Doxa/SISTER, pp. 43-78.

Sannerstedt A (2005) Negotiations in European Union committees. In: Elgström O and Jönsson C (eds) European Union Negotiations: Processes, Networks and Institutions. London: Routledge, pp.97-114.

Schlager E (1995) Policy making and collective action: Defining coalitions within the advocacy coalition framework. Policy Sciences 28(3): 242-270.

Schmidt VA (2008) Discursive institutionalism: The explanatory power of ideas and discourse. The Annual Review of Political Science 11(1): 303-326.

Slaughter A-M (2004) A New World Order. Princeton, NJ: Princeton University Press

SOU [Swedish Government Official Report] (1975) Forskningråd. Stockholm: Utbildningsdepartementet.

Sveriges Riksdag [The Swedish Parliament] (2001) Records of proceeding, 3 June, 2001/002, 16§, anf. 96.

Sveriges Riksdag [The Swedish Parliament](2002) Styrelsen för Stiftelsen Riksbankens Jubileumsfonds berättelse över fondens verksamhet och förvaltning under år 2001 Stiftelsens uppdrag, tillkomst och inriktning. Redogörelse till riksdagen, 2001/02:RJ1.

Thelen K (1999) Historical institutionalism in comparative politics. Annual Review of Political Science 2(3): $369-404$.

Thelen K (2004) How Institutions Evolve: The Political Economy of Skills in Germany, Britain, the United States, and Japan. Cambridge: Cambridge University Press.

Vetenskapsrådet (2003) Annual Report for 2002. Stockholm: Vetenskapsrådet.

Vetenskapsrådet (2008) Annual Report for 2007. Stockholm: Vetenskapsrådet.

Vetenskapsrådet (2010) The Swedish Research Council's Viewpoints on Implementation of ERA and the Design of the Next Framework Programme. Stockholm: Vetenskapsrådet.

Wedlin L and Nedeva M (eds) (2015) Towards European Science: Dynamics and Policy of an European Research Space. Cheltenham: Edward Elgar.

Wigzell H (2002), Framework programmes evolve. Science 295(5554): 443-445.

\section{Author biography}

Bo Persson is Senior Lecturer in Political Science at Linköping University. His research focuses on the formulation and implementation of research and innovation policy in Sweden, on regional and local development policy, and on the role of institutions in policy-making. 